\title{
CHARACTERIZATION OF THE NON-APPARENT CLINICAL FORM IN THE INITIAL PHASE OF SCHISTOSOMIASIS MANSONI
}

\author{
Manoel Otávio da Costa ROCi (1), Enio Roberto Pietra PEDROSO (1), Jayme NEVES (1), Roberto Sena ROCHA (2), \\ Dirceu Bartolomeu GRECO (1), José Roberto I AMBERTUCCI (1), Regina Lunardi ROCHA (1) \& Naftale KATZ (2)
}

\section{SUMMARY}

In this paper the history of 115 recruits that had bathed simultaneously in streams contaminated with Schistosoma mansoni, during military maneuvers, is reported. Thirty four of the infected patients presented the initial phase of the infection diagnosed through epidemiologic, clinical and laboratorial parameters. Three out of the 34 patients did not reveal the clinical picture of the infection, thus being considered representatives of the non-apparent form of the disease.

Differences between the intensity of blood eosinophilia, the area of immediate cutaneous reaction and the number of Schistosoma eggs eliminated in the stools proved not to be statistically significant $(p>0.05)$ when the non-apparent and acute cases of schistosomiasis were compared.

These cases actually may be considered evidences of the non-apparent form hitherto merely taken for granted in the literature.

KEY WORDS: Acute schistosomiasis; Non-apparent form; Initial phase of schistosomiasis.

\section{INTRODUCTION}

Studies of the clinical, pathogenic and therapeutic aspects of the initial phase of schistosomiasis mansoni have not yet led to the accumulation of the same mass and variety of information as is availabe for the chronic forms of the disease $\mathrm{e}^{2,8,4,5,6,8,12,13,14,15,18,19}$.

Although in the initial phase of schistosomiasis mansoni the clinical picture varies somewhat in terms of levels of severity, even those variant forms with expressive symptomatology can frequently be aetiologically overlooked. Very probably the occurrence of the acute form has often been underestimated in both endemic and non-endemic regions, due in part to the polymorphic nature of its manifestation, its low incidence (specially in hyperendemic areas) and also to diagnostic confusion with various diseases prevalent in underdeveloped countries $^{13,19}$.

It has been taken for granted that most of the patients infected with $S$. mansoni do not initially develop apparent clinical manifestations. Despite having been widely referred to in the literature this needs demonstration, and is the aim of this work.

\section{PATIENTS AND METHODS}

\section{Patients}

One hundred and fifteen recruits were studied, all members of the Brazilian Army, who simultaneously came into contact with natural water in the outskirts of Pampulha, Belo Horizonte, Minas Gerais, during training maneuvers, in 1979.

All patients underwent a clinico-epidemiological evaluation by means of filling in a standard questionnaire and undergoing a general clinical examination 2 months after contamination. The patients were all aged between 18 and 19 , and were in good nutritional condition.

(1) Faculdade de Medicina da Universidade Federal de Minas Gerais, Belo Horizonte, MG, Brasil.

(2) Centro de Pesquisas "René Rachou", Fundação Oswaldo Cruz, Caixa Postal 1743, 30190-002 Belo Horizonte, MG, Brasil. 
ROCHA, M.O. da C.; PEDROSO, E.R.P.; NEVES, J.; ROCHA, R.S.; GREGO, D.B.; LAMBERTUCCI, J.R.; ROCHA, R.L. \& KATZ, N. - Characterization of the non-apparent clinical form in the initial phase of schistosomiasis mansoni. Rev. Inst. Med. trop. S. Paulo, 35(3):247-251, 1993.

\section{Methods}

Laboratory evaluation consisted of carrying out a global and specific leucogram, using the Leishman colouring method, and two parasitological faecal examinations, by the quantative Kato-Katz method ${ }^{11}$. Intradermic tests were carried out on the mid-part of the flexural surface of the forearms by injecting $0.05 \mathrm{ml}$ of $S$. mansoni adult worm antigen, containing $40 \mu \mathrm{g} \mathrm{N} / \mathrm{ml}$, prepared by the Instituto de Ciências Biológicas da Universidade Federal de Minas Gerais. After 15 minutes the results were obtained using the measurement of the area of the papule ${ }^{17}$. All patients were submitted to a photofluorographic evaluation around 60 days after the infecting contact, using a Movix 60/120 - Meditécnica machine and Kodak $70 \mathrm{~mm}$ film. The photofluorographs were carried out on postero-anterior incidence analysed blindly by three examiners after being independently and randomly marked with a code. Any alterations identified by at least two of the examiners were regarded as real.

As representatives of the initial phase of the infection individuals were selected who admitted to having come into contact with the natural waters in question up to two months previously and were eliminating $S$. mansoni eggs in their stools; in addition, were also selected those that either developed an acute toxic-infectious picture between 15 and 50 days after the contact under consideration, thereby giving instances of the acute form, or who developed without a specific symptomatology yet presented contemporaneously blood eosinophilia of more than 1000 cells $/ \mathrm{mm}^{3}$ thereby giving instances of the non-apparent form.

Student's " $t$ " test was used to compare the group of patients showing clinical manifestations with the group of asymptomatic patients in regard to the area of intradermic reaction, intensity of blood eosinophilia and number of eggs eliminated in the faeces. The degree of minimum significance considered was $5 \%$.

\section{RESULTS}

Thrirty four individuals presented the initial stage of the infection: $31(91.2 \%)$ with the acute and three $(8.8 \%)$ with the non-apparent form of the disease. These cases are described below.
PATIENT 1 - J.F.L., male, aged 18, dark-skinned, single. He had no clinical symptomatology after the infecting bath contact. He told of previous contact with natural waters in the outskirts of Belo Horizonte, although previous stool examinations were negative. Physical examination was normal. The leucogram showed 20,600 leucocytes/ $\mathrm{mm}^{3}$ and 16,068 eosinophils $/ \mathrm{mm}^{3}$ ( $78 \%$ of the total). The area of intradermic reaction was of $1.4 \mathrm{~cm}^{2}$. Stool examination showed an average of 102 eggs of $S$. mansoni per gramme and the photofluorograph showed no alterations.

PATIENT 2 - J.L.D., male, aged 19, dark-skinned, single. He presented no complaints, despite having admittedly bathed in the waters in question. He reported prior contact with natural waters in the outskirts of the city. Previous faecal parasitological tests proved to be negative for $S$. mansoni eggs. His physical examination was normal. The leucogram showed 10,250 leucocytes $/ \mathrm{mm}^{3}$ and 4,510 eosinophils $/ \mathrm{mm}^{3}$ (44\% of the total). The area of intradermic reaction was of $1.0 \mathrm{~cm}^{2}$ and the faecal examination showed an average of six eggs per gramme. The photofluorograph showed thickening of the bronchial walls at the base of the right lung field.

PATIENT 3 - T.C.O., male, aged 18, dark-skinned, single. No information was available on his previous epidemiological history. He remained asymptomatic after the military manoeuvers. The leucogram showed 8,020 leucocytes $/ \mathrm{mm}^{3}$ and 1,925 eosinophils $/ \mathrm{mm}^{3}(24 \%)$. The area of intradermic reaction was of $0.7 \mathrm{~cm}^{2}$ and the faecal examination showed an average of 18 eggs per gramme. The photofluorograph showed no alterations.

There were no statistically significant diferences between eosinophilia, egg counts and area of immediate intradermic reaction in patients with the acute form of the disease, when compared to patients with the non-apparent form ( $p>0.05)$. (Tables 1 and 2 ).

\section{DISCUSSION}

The acute form of schistosomiasis mansoni is still considered a rare condition today, even in highly endenic areas. In an hyperende- 
ROCHA, M.O. da C.; PEDROSO, E.R.P.; NEVES, J.; ROCHA, R.S.; GREGO, D.B.; LAMBERTUCCI, J.R.; ROCHA, R.L. \& KATZ, N. - Characterization of the non-apparent clinical form in the initial phase of schistosomiasis mansoni. Rev. Inst. Med. trop. S. Paulo, 35(3):247-251, 1993.

TABLE 1

Total numbers of leucocytes and eosinophilis, area of the immediate intradermic reaction and average egg counts of patients with the non-apparent form of schistosomiasis mansoni.

\begin{tabular}{ccccc}
\hline Patient & $\begin{array}{c}\text { Leucocytes } \\
\text { per } \mathrm{mm}^{3}\end{array}$ & $\begin{array}{c}\text { Eosinophils } \\
\text { per } \mathrm{mm}^{3}(\%)\end{array}$ & $\begin{array}{c}\text { Arca of } \\
\text { Intradermic } \\
\text { Reaction }\left(\mathrm{cm}^{2}\right)\end{array}$ & $\begin{array}{c}\text { Average egg } \\
\text { counts } \\
\text { (per gramms) }\end{array}$ \\
\hline JFL & 20,600 & $16,068(78)$ & 1.4 & 102 \\
JLT & 10,250 & $4,510(44)$ & 1.0 & 6 \\
TCO & 8,020 & $1,925(24)$ & 0.7 & 18 \\
\hline
\end{tabular}

TABLE 2

Total numbers of leucocytes and eosinophils, area of the immediate intradermic reaction and average of the egg counts of patients with the acute form of schistosomiasis mansoni.

\begin{tabular}{|c|c|c|c|c|}
\hline Patient & $\begin{array}{l}\text { Leucocytes } \\
\text { per mm }\end{array}$ & $\begin{array}{l}\text { Eosinophils } \\
\text { per mm } \\
(\%)\end{array}$ & $\begin{array}{c}\text { Area of } \\
\text { Intradermic } \\
\text { Reaction }\left(\mathrm{cm}^{2}\right)\end{array}$ & $\begin{array}{l}\text { Average obtained } \\
\text { from faccal egg } \\
\text { counts (per gramms) }\end{array}$ \\
\hline ASM & 7,700 & $2,464(32)$ & 1.4 & 36 \\
\hline AGLR & 12,050 & $4,097(34)$ & 1.0 & 42 \\
\hline AJL & 5,800 & $1,334(12)$ & 1.2 & 12 \\
\hline ARGV & 8,800 & $3,080(35)$ & 1.0 & 336 \\
\hline BVSFo. & 9,950 & $5,472(55)$ & 0.9 & 36 \\
\hline CAM & 13,500 & $8,370(62)$ & 1.2 & 48 \\
\hline CEJB & 18,650 & $5,595(30)$ & 1.1 & 48 \\
\hline FLA & 9,156 & $3,019(33)$ & 1.2 & 30 \\
\hline $\mathrm{GCA}$ & 7,450 & $3,725(50)$ & 1.2 & 66 \\
\hline GAS & 6,550 & $131(6)$ & 1.0 & 66 \\
\hline JBX & 11,000 & $5,060(46)$ & 2.0 & 222 \\
\hline $\mathrm{JP}$ & 13,700 & $6,987(51)$ & 1.4 & 42 \\
\hline JTFo. & 13,450 & $5,514(41)$ & 1.2 & 60 \\
\hline JAVJr. & 13,150 & $6,049(46)$ & 1.2 & 102 \\
\hline L.RC & 11,000 & $5,720(52)$ & 1.2 & 30 \\
\hline LCRM & 4,450 & $1,023(23)$ & 3.3 & 378 \\
\hline LSB & 7,450 & $2,086(28)$ & 1.2 & 12 \\
\hline $\mathrm{MABC}$ & 15,650 & $9,547(61)$ & 3.1 & 432 \\
\hline MBP & 18,750 & $10,500(56)$ & 1.3 & 156 \\
\hline $\mathrm{MCN}$ & 5,850 & $1,327(23)$ & 3.3 & 246 \\
\hline MSV & 8,200 & $2,624(32)$ & 1.1 & 54 \\
\hline NJP & 12,350 & $5,928(48)$ & 0.8 & 60 \\
\hline NAR & 10,650 & $3,088(29)$ & 0.7 & 439 \\
\hline PLR & 8,650 & $3,373(39)$ & 1.2 & 18 \\
\hline PRCC & 10,000 & $2,300(23)$ & 1.0 & 156 \\
\hline PCA & 9,750 & $3,215(33)$ & 3.2 & 120 \\
\hline $\mathrm{RCV}$ & 9,100 & $2,639(29)$ & 2.0 & 54 \\
\hline RAP & 13,900 & $8,618(62)$ & 0.7 & 463 \\
\hline $\mathrm{RPM}$ & 11,300 & $4,520(40)$ & 1.1 & 90 \\
\hline WCM & 10,350 & $6,003(58)$ & 0.9 & 36 \\
\hline WDFo. & 21,950 & $12,292(56)$ & 1.1 & 12 \\
\hline
\end{tabular}

mic region such as Caatinga do Moura in Bahia, BINA \& PRATA ${ }^{1}$, despite having found eggs of $S$. mansoni in the faeces of three-month old breast-fed babies and in 50\% of the children up to five years of age, never had the opportunity to observe patients with the acute form of the disease.

The existence of diverse clinico-pathological manifestations indicates that the pathogenic mechanisms involved are probably multiple and vary in both quality and intensity. Data is not yet available to show which reactions are stimulated by the worms, as well as, the interrelationships that exist between various types of reactivity to the organism, the types of organic lesions or factors capable of modifying general and local reaction in the organism ${ }^{13}$.

The non-apparent form of schistosomiasis, in the endemic and hyperendemic areas has, for a long time, been assumed to lead the 
ROCHA, M.O. da C.; PEDROSO, E.R.P.; NEVES, J.; ROCHA, R.S.; GREGO, D.B.; LAMBERTUCCI, J.R.; ROCHA, R.L. \& KATZ, N. - Characterization of the non-apparent clinical form in the initial plase of schistosomiasis mansoni. Rev. Inst. Med. trop. S. Paulo, 35(3):247-251, 1993.

large majority of patients, into a silent progression towards the chronic form of the infection. Such was the position held by GIRGES ${ }^{7}$ and many others ${ }^{13}$.

One of the selection criteria for patients with initial schistosomiasis was the demonstration of blood eosinophilia of over 1,000 cells per $\mathrm{mm}^{3}$. This finding was also necessary in order to include the asymptomatic patients in the infected group. Since, however, the presence of expressive eosinophilia even though characteristic, is not an obligatory phenomenon in initial schistosomiasis, the frequency of recorded non-apparent cases is possibly not a true reflection of the frequency in the community under natural conditions.

Eosinophilia, a possible pathogenetic factor in acute schistosomiasis ${ }^{21}$, did not constitute the determining element of the clinical picture when taken in isolation. The same was true for the area of immediate intradermic reaction, which already has been related to levels of IgE linked to mastocytes, in patients with both recent and chronic schistosomiasis ${ }^{9}$. Also, there was no significant relationship between the presence of clinical manifestations and the number of $S$. mansoni eggs in the faeces ${ }^{10,20}$. These facts lead us to believe that other factors besides worm burden, are involved in determining the clinical forms of the disease.

The cases here described constitute objective evidence for the non-apparent form, hitherto merely taken for granted in the literature.

\section{RESUMO}

\section{Caracterização da forma inaparente da fase inicial da esquistossomose mansoni.}

Foram estudados 115 recrutas que tiveram contato simultaneamente com águas infectadas pelo Schistosoma mansoni. Trinta e quatro pacientes apresentaram a fase inicial da infecção, diagnosticada através de parâmetros laboratoriais, clínicos e epidemiológicos, sendo que três deles não evidenciaram quadro clínico, sendo considerados como portadores da forma inaparente da doença.

Não se verificou, entretanto, diferença estatística entre a intensidade da cosinofilia sanguínea, as áreas da reação intradérmica de leitura imediata e as médias das contagens do número de ovos de $S$. mansoni eliminados nas fezes, quando se compararam os resultados obtidos em pacientes com as formas aguda $\mathrm{e}$ inaparente.

Os casos ora descritos constituem evidenciação objetiva da forma inaparente, antes apenas presumida na literatura.

\section{REFERENCES}

1. BINA, J.C. \& PRATA, A. - A evoluçāo natural da esquistossomose mansoni em uma área endêmica. In: Aspectos peculiares da infecção por S. mansoni. Salvador, Centro Editorial e Didático da UFBA, 1984. p.1333.

2. CHING, W.H. - Acute schistosomiasis. Clinical manifestations of 96 cases. Chin. med. J., 76:1-10, 1958.

3. COURA, J.R.; CAMILLO-COURA, L.; KALACHE, A. \& ARGENTO, C.A. - Esquistossomose aguda autóctone de foco na cidade do Rio de Janeiro. Estudo de 22 casos. Rev. Soc. bras. Med. trop., 4:387-397, 1970.

4. DIAZ-RIVIERA, R.S.; RAMOS-MORALES, F.; KOPPISH, E.; GARCIA-PALMIERI, M.R.; CINTRÓN-RIVERA, A.A.; MARCHAND, E.J.; GONZALES, O. \& TORREGROSA, M.Y. - Acute Manson's schistosomiasis. Amer. J. Med., 21:918-943, 1956.

5. FERREIRA, H.; OLIVEIRA, C.A.; BITTENCOURT, D.; KATZ, N.; CARNEIRO, L.F.C.; GRIMBAUM, E.; VELOSO, C.; DIAZ, R.P.; ALVARENGA, R.J. \& DIAS, C.B. - A fase aguda da esquistossomose mansoni. Consideraçōes sobre 25 casos observados em Belo Horizonte. J. bras. Med., 11:54-67, 1966.

6. FERREIRA, L.F, \& SILVA, J.R. - Fase toxêmica da esquistossomose mansoni. Consideraçōes a propósito de alguns casos coletivamente contaminados em uma piscina. Rev. Inst. Med. trop. S. Paulo, 2:112-120, 1960.

7. GIRGES, R. - Schistosomiasis (Bilharziasis). London, John Bale Sons \& Danielson, 1934.

8. GREGO, D.B.; PEDROSO, E.R.P.; LAMBERTUCCI, J.R.; ROCHA, M.O.C.; COELHO, P.M.Z.; RASO, P. \& FERREIRA, C.S. - Pulmonary involvement in schistosomiasis mansoni. Mem. Inst. Oswaldo Cruz, 82:221$227,1987$.

9. HUSSAIN, R.; HOFSTETTER, M.; GOLDSTONE, A.; KNIGHT, W.B. \& OTTESEN, E.A. - IgE responses in human schistosomiasis. I - Quantitation of specific IgE by radioimmunoassay and correlation of results with skin test and basophil histamine release, Amer. J. trop. Med. Hyg., 32:1347-1355, 1983.

10. KATZ, N. - Avaliação terapêutica do hycanthone em pacientes com período de infeç̧ão esquistossomótica conhecido. Rev. Soc. bras. Med. trop., 5:55-60, 1971. 
ROCHA, M.O. da C.; PEDROSO, E.R.P.; NEVES, J.; ROCHA, R.S.; GREGO, D.B.; LAMBERTUCCI, J.R.; ROCHA, R.L. \& KATZ, N. - Characterization of the non-apparent clinical form in the initial phase of schistosomiasis mansoni. Rev. Inst. Med. trop. S. Paulo, 35(3):247-251, 1993.

11. KATZ, N.; CHAVES, A. \& PELLEGRINO,J. - A simple device for quantitative stool thick-smear technique in schistosomiasis mansoni. Rev. Inst. Med. trop. S. Paulo, 14:397-400, 1972.

12. LAMBERTUCCI, J.R.; PEDROSO, E.R.P.; SOUZA, D.W.; LIMA, D.P.; NEVES, J.; SALAZAR, H.M.; MARINHO, R.P.; ROCHA, M.O.C.; COELHO, P.M.Z.; COSTA, M.F.F.L. \& GRECO, D.B. - Therapeutic efficiency of oral oxamniquine in the toxemic form of sclistosomiasis mansoni: treatment of eleven individuals from two families and experimental study. Amer. J. trop. Med. Hyg., 29:50-53, 1980.

13. NEVES, J. - Esquistossomose mansoni, Clínica da forma aguda ou toxêmica. Rio de Janeiro, Medsi, 1986.

14. NEVES, J.; MARTINS, N.R.L.L. \& TONELLI, E. Forma toxêmica da esquistossomose mansoni. Consideraçôes diagnósticas em torno de 50 casos identificados em Belo Horizonte. An. Fac. Med. Minas Gerais, 22:75-98, 1965.

15. NEVES, J. \& RASO, P. - Estudo crítico do tratamento da forma toxêmica de esquistossomose mansoni. Ilospital (Rio de J.), 64:167-212, 1963.

16. NEVES, J. \& SOUZA, D.W. - Infecçōes causadas por trematódeos sanguíneos. In: NEVES, J. Diagnóstico e Tratamento das Doenças Infectuosas e Parasitárias. $2^{2}$ ed. Rio de Janeiro, Guanabara Koogan, 1983. p.887917.
17. PELLEGRINO, J. \& MACEDO, D.G. - Novo critério de leitura da reação intradérnica na esquistossomose. Rev. bras. Malar., 8:499-509, 1956.

18. ROCHA, M.O.C. - Estudo das alterações clínicas e radiológicas pulmonares da fase inicial da esquistossomose mansoni humana. Belo Horizonte, 1983. (Tese de Doutoramento - Faculdade de Medicina da Universidade Federal de Minas Gerais).

19. ROCHA, M.O.C.; PEDROSO, E.R.P.; KATZ, N.; ROCIIA, R.S.; GRECO, D.B.; LAMBERTUCCI, J.R.; ROCHA, R.L. \& NEVES, J. - Manifestaçōes clínicas da fase inicial da esquistossomose mansoni humana. In: CONGRESSO DA SOCIEDADE BRASILEIRA DE MEDICINA TROPICAL, 25, Florianópolis, 1989. RESU. MOS. Florianópolis, 1989. p.83-84.

20. ROCHA, R.L.; ROCHA, M.O.C.; COELHO, P.M.Z.; PEDROSO, E.R.P.; OLIVEIRA, T.R.F.; BICALHO, S.M. \& SILVA, E.S. - Relação da eliminação de ovos com a carga parasitária na evolução da esquistossomose mansoni experimental. In: CONGRESSO DA SOCILDADE BRASILEIRA DE MEDICINA TROPICAL, 25, Florianópolis, 1989. Resumos. p.80.

21. WELLER, P.F. - Eosinophilia. J. Allergy clin. Immunol., 73:1-10, 1984 .

Recebido para publicação em 10/09/1992 Aceito para publicação em 04/01/1993 